\title{
Updike's Bech: A Book, and the Heaven of Fiction
}

\author{
Ana María Manzanas Calvo \\ University of Castilla-La Mancha
}

\begin{abstract}
This paper examines Bech's trajectory as a fictional character and as an artificer of words. Bech, the word master, is "reduced" throughout the novel in the several oeuvres which try to capture his essence until finally he enters the "heaven of fiction," the ultimate reduction which fixes him as an immortal, immutable character. Bech, however, longs for the mortality of life outside the pantheon, for the unlimited possibilities of reality.
\end{abstract}

Is there no change in paradise?

Does ripe fruit never fall? Or do the boughs Hang always heavily in that perfect sky ...?

Wallace Stevens, “Sunday Morning”

In the middle of Bech's curriculum of amatory episodes, good humour, helpless decadence, and impotence, the reader is surprised with an apparently pointless incursion into his childhood. Bech's mother leads him to a sanctuary of wisdom, the "haven of lasting accomplishment" (John Updike Bech: A Book 137); striking as it sounds, "Bech Enters Heaven." In terms of informativity (Beaugrande and Dressler Introduction to Text Linguistics 8-9), "Heaven" is a surprising concept for the reader; by spreading activation (Introduction to Text Linguistics 88), the concept brings to mind a series of experiences, memories, or mere speculations related with a feeling of ease and timelessness. Within the novel, Bech's visit to Heaven marks the contingent beginning of his literary call and his pursuit of inspiration. His "awakening" to the world of art represents the ignition of his own writing and of the book (Bech: A Book) itself. This paper intends to delve into the nature of Bech's artistic heaven, a place, as Wallace Stevens suggests in "Sunday Morning" (Collected Poems 69), deprived of the imperfection of death, change, and mutability. 
Bech's unprecedented return to his childhood breaks the rhythm of his episodic decline. Not only is the incident striking for the reader, but for young Bech as well; his vision exceeds his conception of space (young Bech is shocked his mother and he have to take a train), and his intuitions about the chances of human achievement. Bech envisions the participants of the ceremony as those who enjoy "their immortality" (136): "Each face, even at the distance of the balcony, displayed the stamp of extra precision that devout attention and frequent photography each upon a visage; each had suffered the crystallization of fame" (136). Equally remarkable is the way the narrator has integrated the occurrence as a perfect memory in Bech's mind, as if Updike himself were "burning" the episode as an orgasmic experience in Bech's early life (see Bech's theory on the orgasm, p. 58).

Bech's truancy follows the narrator's plan to present the child's first moment of admiration for the imperishable world of the word and fame. Bech beholds almost incredulously the fixity of each of the faces and longs for "their transcendence of time." For young Henry Bech, the characters his mother located and pointed out to him "had attained the heaven of accomplishment and exempted themselves from the nagging nuisance of growth and its twin ... decay" (137), which as a child he already intuited in his very distinguishable physicality ("big nose and big feet" [131]). For Henry, these men and women were beyond the uncertainties of his world. When mother and child leave the pantheon, young Bech is perceptibly impressed with the vision of those immortal souls. From that very moment, Bech, like the men and women he saw in the pantheon, was to pursue an elusive inspirational muse throughout his life: "His ears were red, showing that an inner flame had been lit. She [Henry's mother] had set him on a track, a track that must be ... the right one" (137). This moment of inner revelation and aesthetic arrest offers a frame for Bech's "Second Coming" to the same stage three decades later not as an espectator but as an active participant. It is precisely this first experience that provides a pattern for his second visit. However, Bech does not immediately remember the expedition with his mother. In fact, Bech seems unaware of the development of the book and of the narrator's arrangement of his two visits to the Pantheon. The narrator "crafts" Bech's second coming as an award after a pilgrimage (p. 80) in search of inspiration. The lay-out of Bech: A Book is a series of episodes as in an itinerant novel. Bech's life is fictionalized according to a gradation towards the achievement of a goal. The writer's fictionalization of Bech as a character is an instance of the asymmetry between life and fiction. Updike has selected material from Bech's letters, his diary, and possibly his interviews to produce an actual fictional system from the multiple range of possibilities reality offers; even if this reality has already been violated and made concrete in the entries of Bech's diary, or in the contained love letter. Fiction is then the crystallization of reality, however fictitious this reality (Bech's existence) might be.

Within the book, Tuttle's ouvre is supposed to act as an instance of the lack of correspondence between reality and fiction. Tuttle tries to cover skillfully (almost invisibly) the variable margin of deformation between Bech and his fans, between his life and his fictionalized existence: 
What I have in mind now is a chance for you to explain yourself, to say everything you want to say. You want to say. Your name is known over here, Mr. Bech, but they don't really know you. (109)

He even offers himself to judge Bech's coherence of thoughts so as not to alter the fluency of his tape. Tuttle takes pains to make Bech understand that his mediation in the interview is going to be transparent, that if he used him "hard enough," Bech would have a chance "to make a definite testament" (111). Tuttle's interview intends to be-like fiction-" the equivalent of reality" (110), an arrangement of thoughts and sentences "creating a tightness perhaps equivalent to the terribly knit of reality" (110). So tight does Tuttle want to make it that there must be no deviation, no change and no chance; it must be Bech's definite "testament." Within the context of the book, the interview could be a legitimate, coherent summing up of Bech's conceptions on fiction and reality, on words and his life. However, Bech is hardly surprised to find that his Bech's Best is disqualified in Tuttle's article "Bech's Best Not Good Enough." Neither is he taken aback when he finds that

Almost none of the quotes he had poured into the boy's notebook and tape recorder were used. Instead, an aggrieved survey of Bech's oeuvre unfolded, smudged by feeble rebuttals. (128)

Tuttle's interview becomes his own oeuvre, another "vapid and doctrinary review" (121) in which Bech's life is utterly ignored. Tuttle's article contrasts sharply with MERISSA's playful, telegraphic WEEK. Merissa's column captures the fragmentary pieces of Bech's "existential" "transatlantic" existence and of her (maybe also segmented) knowledge/love for him. She lovingly and thankfully appropriates Bech's smashing, "rabbinical curls" (129). Bech sees no harm in Merissa's appropriation of his diction nor in her semblance of him. Bech has the feeling (and so does the reader), that their nights and conversations together have been legitimately put into words. She has made an accurate version of Bech and he sanctions it once he is on the plane: "Bech closed his eyes, feeling his love for her expand as the distance between them increased" (130).

The same distance between Bech's thoughts and Tuttle's interpretation of them in his oeuvre, separates the living performance (98) Bech has become for his admirers and his "real" life. Bech acknowledges that "he had become a character by Henry Bech" (130). When he questions "What was he?" His own manipulation of words grants him a gradually low definition in the chain of being:

A con artist in the days of academic modernism undergoing a Victorian shudder. A white monkey hung far out on a spindly heaven tree of stars. A fleck of dust condemned to know it is a fleck of dust. A mouse in a furnace. A smothered scream. (98)

In terms of coherence there is a diminution of his being, and of his living and thinking capabilities. In this rapid progression towards the non-being, he ceases to exist as syntax undergoes a similar reduction; from the elaborate articulation of his existence as an artist to the simple statement of his animalistic, almost nihilistic stage, a life-time has been 
consumed, reduced. His reduction through words in Tuttle's oeuvre is only a pattern Bech himself is replicating is his own minimization.

Not in vain Bech is "panicking," as he recognizes and accepts himself as a public figure, "a fictional version" (126) others have created. To replicate the pattern of artificial creation, the narrator warns the reader that "this moment in Bech's pilgrimage must be approached reverently, hesitantly, as befits a mystery" (80). The narrator seeks the reader's consent to narrate (almost create out of nothing) "Bech Panics" through a "few slides" (see p. 80). Out of the slides the narrator recreates a full episode, a variety of dialogues and situations which are mere speculations on reality. The slides, which pretend to be actual snap-shots of reality are in turn re-actualized in the making of the episode. The actual reality is thus twice removed from the real occurrences. The elaboration of "Bech Panics" becomes a mere experiment, only an actualization, "a running impoverishment of possibility" ("The Bulgarian Poetess" 58). Thus entrapped by his own public figure, Bech would need to be rescued like he had rescued the girls and women he had loved at some point. The narrator makes use of the same pattern Bech used to master when he was the creator of the situation (when Bech was the speculator of the needs of the girls, the statue, and the embassy wife among others). Captured by the "cold grip" (52) of time, Bech observes the tantalizing invitation of spring fleshing out in the inviting, overwhelming "massed fertility" (8y) of the "charming daughters of fertile Virginia" (88). Reduced to impotence in such avalanche of earth-smells and pent-up fertility, he reflects on the "inhuman mutual consumption that is Nature" (95). While contemplating the blooming daffodils in London, Bech could very appropriately say with Eliot that "April is the cruelest month, breeding/Lilacs out of dead land, mixing/Memory and desire, stirring/Dull roots with spring rain" (The Waste Land, Selected Poems), when time is the last narrator, the definite reducer of the unlimited possibilities of life; when impotence replaces vital potency but active, pent-up passion remains intact.

The narrator paces Bech's "angst" (97) throughout "Bech Panics" and "Bech Swings" to culminate Bech's escalation in impotence with "Bech Enters Heaven." Bech's entrance respects the coherence of the context since it comes about as any other casual invitation to join "the Erotica Book Club or the Associated Friends of Apache Education" (138). Only, this time the narrator's intentionality is made manifest; Bech's entrance in this exclusive Academe appears as the goal of the book, the finality which seems to have been present not in Bech's mind (the narrator informs the reader that Bech "did not connect the honour with his truant afternoon of over three decades ago" 138), but in the arrangement of episodes which compound the book. However close the narrator arranges both visits, they are an "artistic" life apart. The ellipsis between them corresponds to the rest of the episodes. Between the first entrance-ideation-and the second-goal-the novel unfolds and organizes its chapters. The second entrance to Heaven, then, completes Bech's pilgrimage through the book; he enters the sanctuary of fame and immortality. The "nagging nuisance of growth and its twin ... decay" yields to Bech's "lasting accomplishment" (137). The multiform facets and sides of reality and possibility find their last image in the "labyrinthine" disposition of corridors and stairways. The possibilities of Bech's pilgrimage crystallize in fiction, in the cohesive and coherent arrangement which constitutes the book. Like the faces he contemplated in his 
childhood, Bech has suffered the crystallization of fame; he too enjoys now his immortality. Unlike young Henry, Bech has experienced through the book the high cost of the immortality of fame; to be immortal, to be integrated in the pantheon of immortality, one has to be previously mortal, one has to deny and die to the possibilities of the polymorphic reality. Bech's life is structured from an idea to the completion of a plan according to an overt case of situation management; Updike doses and tames Bech's vital ardour and veer into the structured, fictional episodes which compound the apparatus of the novel. As he is submitted to the formal immortality that is fiction, Bech dies to the open, virtual world of possibility. Bech's human, almost real extravagance surpasses in the mind of the reader the domain assigned to a character of fiction. Situationality reminds the reader that it is only within the frame of a text type-novel-that Bech's life is formally cohesive in clear-cut episodes, and coherent in the pattern Updike has designed for the novel.

Bech's entrance into Heaven, which coincides with the consummation of the action of the novel and of Bech's literary career, strikes the reader as the entrance into the immortal Heaven of fiction, into the novel itself. The reader then considers in retrospect the tight actuality of the novel as a text-type, a coherently and cohesively articulated system of episodes which makes use of the literary licences the text-type offers. On the formal level, the novel is acceptable to the reader and should be to Bech as well as a word-maker, and as an artificer of fiction. Nevertheless, and adding to the level of informativity of the text, Bech does not seem to submit to his role as a fictitious character condemned to be immortal. Once in his planned and arranged Heaven, he questions which the next stage is: "Now what?" (143). Bech is already longing for the mutability, or the mortality of life. He wonders if this is "it," the threshold of termination, of his termination as a live character; the reader does, too. Updike himself answers Bech and the reader's "existential" question by publishing Bech is Back, a sequel to Bech: A Book. In this sense, Bech as a character is continued and revitalized; Bech is ready to exercise once more the fictitious possibilities of reality. However, if the reader takes Bech: A Book as an autonomous text world, Bech is bound to the indisputable Heaven of the novel, a place where, in Wallace Stevens' words, "there is no change of death" ("Sunday Morning" Collected Poems 69).

The reader questions if Bech's Heaven is the Heaven of fiction, a more or less capricious and contingent, although immortal representation of reality; and with Bech, the reader hesitates to accept that the immortality of fiction is able to compensate for its reductive, asymmetrical equivalence of reality. Moreover, the reader is uncertain about the criteria the narrator has followed to ficionalize Bech's entries in his diary, and how Bech's love letter in Appendix A has been utilized as literary matter. The narrator gives no explanation; the book is meant to be self explanatory. Bech's voice is quietened but he gains in immortality as the main character of a text-type, a master work in word-performance. Bech's fictionalization in the book follows the same pattern, although on a larger scale, as Tuttle's oeuvre. Both, Updike and Tuttle, create subjective captures of Bech's reality in an act of possession. Both commit an imposition of the self on the open world of reality; both direct the course of words following a goal and projecting themselves on it. 
Like Bech, reality yields to the elaboration, the craftsmanship, credibility, and the immortality of fiction. Bech: A Book, Updike's oeuvre, is located within the margin of the reader, reality, and Bech's acceptability. Bech himself sanctions the book with the same distance he accepted Tuttle's ouvre, wondering if the character respects his (Bech's) integrity: "I wonder if it is me, enough me, purely me" (9). Bech questions to what extent Updike has imposed his own principles and fears. He finds in the book "something Waspish, theological, scared, and insinuatingly ironical that derives," this is Bech's "wild surmise," from Updike himself. Bech does not deny the legitimacy of the appropriation of his name and persona, but he might recall with melancholy Merissa's subjective, although down right and honest version of him. Bech "blesses" the book as a "running impoverishment of possibility," just one of the multiple configurations of reality which will perpetuate the asymmetry between life and fiction. Reality, however, will not be "drastically" harmed, nor will be Updike, nor will be Bech himself: "I don't suppose your publishing of this little jeu of a book will do either of us drastic harm" (10).

\section{Works Cited}

Beaugrande, Robert D. and Dressler, Introduction to Text Linguistics. London: Longman, 1981. Eliot, T. S. Selected Poems. London: Faber, 1982.

Stevens, Wallace. The Collected Poems. New York: Vintage, 1982.

Updike, John. Bech: A Book. Harmondsworth: Penguin, 1980. 